ŁUKASZ DOMINIAK

Instytut Politologii UMK

\title{
Przeciw liberalizmowi i komunitaryzmowi
}

Dowyższy tekst pochodzi z przedmowy do drugiego wydania opus magnum Michaela Sandela Liberalism and the Limits of Justice. W literaturze przedmiotu uważa się, iż praca ta rozpoczęła tzw. spór liberałów z komunitarystami - Sandel przedstawia w niej kompleksową krytykę Teorii sprawiedliwości Johna Rawlsa. Pomijając wątpliwości dotyczące datowania początku komunitaryzmu i wiązania go z faktem publikacji Liberalism..., bez wątpienia książka Sandela jest sztandarową pozycją tego nurtu filozoficznego. 
W Prawie do wolności wyznania widać jednak wyraźne wątki antykomunitarystyczne. Sandel nie tylko krytykuje liberalną interpretację prawa do wolności wyznania jako przypadku ogólnej wolności wyboru, ale także komunitarystyczną tezę o wspólnotowej definicji dobra. O ile pierwszy rodzaj krytyki jest przedstawiony w powyższym tekście expressis verbis (autor błyskotliwie i konsekwentnie wskazuje sprzeczności, do jakich prowadzi liberalizm), o tyle drugiego trzeba szukać raczej między wierszami.

Komunitaryzm przyjmuje, iż uzasadnieniem dla istnienia bądź wprowadzenia danego uprawnienia jest pytanie, czy promuje ono podzielane w danej wspólnocie wartości. Te wspólnotowe wartości tworzą tożsamość człowieka. Jaźń oderwana od konkretnych ról i koncepcji dobra - taka, jaką prezentuje Rawls w Teorii sprawiedliwości - jest w rzeczywistości nie do pomyślenia, jest wydumanym abstraktem, który na domiar złego prowadzi koncepcje liberalne do paradoksów (co wykazał m.in. Sandel). Zakorzenienie we wspólnocie jest dla natury ludzkiej, jak zauważa Piotr Przybysz, kwestią konstytutywną. Człowiek nie wybiera w sposób absolutnie wolny swych wartości, wizji dobra i ról społecznych, lecz jego tożsamość jest przez nie tworzona, jest ona poniekąd nimi. Rozbicie, deprecjacja wspólnoty musi oznaczać kryzys tożsamości jednostek oraz pozbawienie ich kompasu moralnego. Takie naruszenie wspólnotowych definicji dobra i zła, piękna i szpetoty, prawdy i fałszu (zob. koncepcja racjonalności A. MacIntyre'a) dokonuje się we współczesnym świecie w wyniku rozwoju i dominacji ideologii liberalnej oraz jej aplikacji do życia społecznego. Liberalne uzasadnianie uprawnień w oderwaniu od podzielanych we wspólnotach wartości a oparcie ich na woluntarystycznej (przede wszystkim) antropologii, prowadzi do zrównania rzeczywistych dóbr ze zwykłymi preferencjami.

Jednak podobnie jak liberalizm w swej woluntarystycznej antropologii rodzi wnioski paradoksalne, tak też - zdaniem Sandela - komunitaryzm w swym wspólnotowym relatywizmie pomija krytyczną rolę sprawiedliwości. Według koncepcji komunitarystycznych sprawiedliwe jest bowiem to, co promuje dobro definiowane właśnie we wspólnocie. Jednak jest sprawą jasną dla każdego zdrowo myślącego człowieka, który obserwuje życie polityczne i bada historię, iż wspólnoty mogą być zarówno szlachetne, jak i zbrodnicze. „Planów i zaangażowań będących podstawą samookreślenia może bowiem być cały przekrój, od godnych podziwu i heroicznych do obsesyjnych i demonicznych. Usytuowane [situated] jaźnie mogą okazać solidarność i głębię charakteru, ale też przesądy i filisterstwo." Znaczy to, iż musi istnieć niezależna od wspólnoty instancja moralnej oceny samej wspólnoty i podzielanych w niej wartości. Jak wskazał Michael Sandel w On Republicanism and Liberalism, twierdzenie, iż „wartości, które przeważają w jakiejkolwiek 
wspólnocie, w jakimkolwiek czasie są sprawiedliwe” jest „rodzajem moralnego relatywizmu”. Co więcej, „zwykły fakt, iż pewne praktyki są sankcjonowane przez tradycję jakiejś partykularnej wspólnoty, nie jest wystarczający, aby uczynić je sprawiedliwymi. Traktowanie sprawiedliwości jako wytworu konwencji jest pozbawianiem jej krytycznego charakteru."7

Sandel odchodzi więc w tym miejscu od "typowego" komunitaryzmu i występuje z jego krytyką. Aby uzasadnić dane uprawnienie, należy wskazać, czy promuje ono jakieś faktyczne ludzkie dobro, które jednak rozpoznawane jest poniekąd niezależnie od kontekstu wspólnotowego. Takie rozpoznanie dokonuje się w drodze rozumowej odpowiedzi na pytanie, jaki rodzaj życia człowieka jest najbardziej godny pożądania bądź jakie cnoty są właściwe dobremu obywatelowi. Wymaga więc wydania właśnie substancjalnego sądu o moralnej wartości praktyk, które dane uprawnienie promuje. W tej mierze też Sandel jawi się raczej jako przedstawiciel koncepcji perfekcjonistycznych czy teleologicznych, niż komunitarystycznych - zbliża się bardzo do etyki Arystotelesa.

Komunitaryzm Michaela Sandela przejawia się zaś w antropologicznej koncepcji jaźni radykalnie usytuowanej (we wspólnocie). Jednak moralna wartość tego usytuowania musi zostać oceniona niezależnie od samego usytuowania - w drodze sądu substancjalnego o dobru bądź złu praktyk danej wspólnoty. Człowiek nie jest więc ani bytem absolutnie niezależnym od kontekstu społecznego, jak głosi liberalizm, ani jednostką „całkowicie” uwarunkowaną wspólnotowo, jak twierdzi komunitaryzm - jest jaźnią radykalnie usytuowaną, lecz wyposażoną w zdolność krytycznego ustosunkowania się do własnej partykularnej wspólnoty.

\footnotetext{
${ }^{6}$ M. Sandel, On Republicanism and Liberalism, "The Harvard Review of Philosophy", wiosna 1996, s. 67.

7 Tenże, Liberalism and the Limits of Justice, Cambridge 1998, s. xi.
} 